\title{
Influx of money and the Manchester City Success Story
}

\author{
Ajinkya Kelkar \\ (Symbiosis Institute of Business Management)
}

Article History: Received: 10 November 2020; Revised 12 January 2021 Accepted: 27 January 2021; Published online: 5 April 2021

\begin{abstract}
The Premier League in the 21st century has been the most popular league in football history. Known for its jaw dropping matches and unpredictability, the teams in this league are quickly establishing themselves as some of Europe's finest football teams. One such team is Manchester City. In 2008 Man City's fortune was overturned when the Abu Dhabi United Group decided to purchase Manchester city under its subsidiary City Football group. The new investors provided city with much needed financial backing because of which they were able to improve their training centre, grounds and medical facilities and It also enabled them tobuy young and established talent. In this study we will attempt to establish a relationship between the money invested by City Football Group in Manchester City and try to relate it to City's success over the last couple of years
\end{abstract}

Keywords: Manchester city, Money, Expenditure, Premier League, Football

\section{Introduction}

Manchester city weren't always the high pressing, technical passing and high goalscoring team like they have been for the past few years. In fact, in the 2000 - 2001 the Manchester city team under Kevin Keegan saw some pretty dark days. They finished 18th on the premier league table which meant relegation to the first division.After a hard-fought battle in the first division city managed to return back to the premier league within the year. City managed to finished 9th in the 2002-2003 season after winning 15 games, drawing 6 and losing 17 games.

Manchester City avoided relegation in the 2003-2004 season finishing 16th on the Premier League table.City soon after decided to disband their home stadium, Maine Road and moved into the newly constructed City of Manchester Stadium (Later changed to Etihad Stadium). The following season was another hard battle for the Cityzens. City managed to scrape through finishing two spots above the relegation zone. City managed to finish mid table in the 2004- 2005 Premier League season with top scorers Robbie Fowler and academy graduate Shawn Wright-Phillips firing the club into 8th place. 2005-2006 season also proved to be yet another devastating season. The appointment of new manager Stuart Pearce didn't seem to change things for the better with the club finishing 16 th on the table winning 13 games while losing 21. The 2006-07 season was tough for the club as they faced the threat of relegation all throughout the season but ultimately finished at 14th place. In December 2006, the club was speculated to be bought out and on June 21, the board accepted an 81.6 million offer from Thaksin Shinawatra. Sven-Göran Eriksson was appointed as the new manager.

It was time for Manchester City to rise to the occasion after spending past 4 years in the bottom half of points table. They were in desperate need of a new direction and leadership from the incoming talent as well as the new leadership. Consequently, the new funds came in and

Eriksson was proactive in the transfer market adding high profile players to the city squad at the cost of 30 million euros. As a consequence of a successful transfer market acquisitions, Manchester City started the new season on a high and mostly stayed at the top 5 positions on the table. Unfortunately, they were not able to replicate the success they had early on in the season and because of this inconsistency they slipped down to ninth position. This loss of form in the final months also led to Shinawatra summarily sacking Eriksson and replacing him with Mark Hughes.

The 2008-2009 season was a rather important one, Manchester city was taken over by Abu Dhabi-based Abu Dhabi United Group Investment and Development Limited, under the ownership of Sheikh Mansoor and newly appointed Chairman Khaldoon Al Mubarak. The sale of the club took place on 1st September on the deadline day for a reported $£ 200$ million. The new owners also immediately signed Robinho from Real Madrid for a club record $£ 32.5$ million. 


\section{Literature Review}

Wages are an important expense for any team. It not only affects the balance sheet but also plays a role in a team performance. There have been few studies completed regarding the direct effect of individual goalie performance measures in predicting salary. Tournament theory would suggest that players who perform better will receive higher pay, and players who are paid less would try and increase their performances to increase their salaries. (Fullard, 2012)

A lot of money is involved with the transfers of top players in the big European football leagues. For various reasons, obtaining a good economic valuation of football players throughout the year is valuable, in other words, not just when a player has just transferred. Furthermore, it is relevant to consider how the market value of a player relates to the performance of that player. (Miao He, 2015). In accordance to this, we might also consider market value of a team with its cumulative performance and parameters that indicates the performance.

Der Spiegel, a German weekly did an expository piece on Manchester City's financial practices. It brought to many people's attention the heavy money being spent by the owners of the club and its effects. (Manchester City Exposed, 2018)

Our aim of writing this research paper is to examine the relationship between factors that on face value do not seem to have a direct relationship between them but do have a correlation. As prior research suggested, there are correlations of Money and Performance of a team, we decided to take Manchester City as a subject. As a lot of unquantifiable factors come into picture when we consider a game like football, we tried to understand how influx of money is co- related to a lot of quantifiable factors which are essential for a team to win major titles. With every season, Manchester City is getting stronger by buying world class players.

As money plays a key role in acquiring players, we decided to consider money spent not just on players but the entire staff who's responsible for the performance of the team, including players, coach, assistant coach, ground staff, physiologist etc. With the sudden rise of City with change of ownership, money can be seen as a powerful tool to win trophies in 21st Century. As the scope of winning trophies includes a lot of factors as player's health, team bonding and manager's bonding with the team, more research in the area of Manchester City can be done.

We also have cited the example of Arsenal football club and how their fortunes turned for the worse when they found themselves out of cash due to the decision of shifting to a new stadium. Manchester city in recent years has become a template for success and many teams have adopted the same practices to emulate their success.

In football, a lot depends on the leadership. By this we don't mean just the owners but also the manager of the team. Teams like Manchester United have seen a lot of success due to the exemplary managerial style of their manager Sir Alex Ferguson. Manchester City changed that. Football as a game has evolved over the years and modern football is driven by money. We have studied only the tangibles. A lot of scope still remains when it comes to intricately studying the passing techniques, the different type of plays and pure statistical analysis of each minute spent in a football game in order to declare what works and what doesn't.

\section{Research Methodology}

Step 1: Identification of parameters

In this step we identified the important parameters that show the performance levels of a football team as well as the financial parameters that attract world class players and managers. The footballing parameters we identified were-

Points Table: This is a parameter that truly reflects the cumulative performance of a team at the end of 38 matches played over a season. This ultimately decides the winner of the Premier league

Goal Difference: This parameter not only shows the amount of goals scored by a team but also the goals conceded. Goal difference was one parameter that encompasses the attack as well as the defence of a team. The overall health of the team is reflected by the goal difference.

The financial factors that we chose were-

Aggregate payroll of employees: Money spent on human resource is the most important task a football club undertakes. Wages become the topmost priority in this regard. Payroll of employees include the wages given to the footballers as well as the manager, assistant coaches, medical staff, kit managers and pitch curators. This keeps the overall moral of the club high as their performances are incentivised. The financial stimulus drives the players as well as other employees to work as hard as they can because they feel that the club is taking care of them.

Net Capital Expenditure: The net capital expenditure is a function of how fast a firm is growing or expecting to grow. High growth firms will have much higher net capital expenditures than low growth firms. 
Market Value of the club: World class players and managers are attracted to the clubs with high market values. These clubs also attract lucrative sponsorship deals which in effect is an attractive feature for star players. A club like Manchester City has been able to sign the best players of this generation because of the market appeal and a promise to win.

Step 2: Collection of data

We have collected this data from Manchester City’s annual reports from 2009 to 2018.

The information about points on table and goal differences were collected from the official website of Barclays Premier League.

Step 3: Statistical Analysis

We used SPSS 2016 version to process the data collected.

We looked for correlations between the chosen parameters and tried identifying future trends using fit line and scatter plot.

We compared points on table of Arsenal, Chelsea and Manchester City from years 1996 to 2019 in order to understand the trends that prevailed over the years for top Premier league teams like them. These trends were showcased through a graph to show the sudden rise of Manchester City in comparison with other top teams like Arsenal and Chelsea.

Dataset

Figure.1 Available data for Manchester City (2008-2018)

\begin{tabular}{|c|c|c|c|c|c|c|}
\hline da Year & Aggregatepayrollcost & PointsonTable & $\$$ GoalDifference & 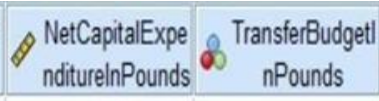 & $\begin{array}{l}\text { MarketValueoth } \\
\text { eclublnPounds }\end{array}$ & Pointsofwinners \\
\hline 2008.09 & 82633000 & 50 & 8 & 97405000 & 325000000 & 90 \\
\hline $2009-10$ & 133306000 & 67 & 28 & 164263000 & 360300000 & 86 \\
\hline $2010-11$ & 173977000 & 71 & 27 & 156812000 & 409500000 & 80 \\
\hline $2011-12$ & 201789000 & 89 & 64 & 124878000 & 483250000 & 89 \\
\hline $2012-13$ & 233106000 & 78 & 32 & 119376000 & 452250000 & 89 \\
\hline $2013-14$ & 205044000 & 86 & 65 & 175108000 & 493300000 & 86 \\
\hline $2014-15$ & 193821000 & 79 & 55 & 128467000 & 434450000 & 87 \\
\hline $2015-16$ & 197584000 & 66 & 30 & 86763000 & 526650000 & 81 \\
\hline $2016-17$ & 264133000 & 78 & 41 & 176579000 & 605450000 & 90 \\
\hline $2017-18$ & 259634000 & 100 & 79 & 291300000 & 1020000000 & 100 \\
\hline
\end{tabular}

\section{Data Analysis}

Figure 2. Correlation between Goal difference and Average Payroll costs

\begin{tabular}{|c|c|c|c|}
\hline & & Goal Difference & $\begin{array}{l}\text { Average Payroll } \\
\text { Costs }\end{array}$ \\
\hline \multirow[t]{4}{*}{ Goal Difference } & Pearson & 1 & $.665^{*}$ \\
\hline & Correlation & & \\
\hline & Sig. (2-tailed) & & .036 \\
\hline & $\mathrm{N}$ & 10 & 10 \\
\hline \multirow[t]{3}{*}{$\begin{array}{l}\text { Money spent on employees } \\
\text { including players(In pounds) }\end{array}$} & $\begin{array}{l}\text { Pearson } \\
\text { Correlation }\end{array}$ & $.665^{*}$ & 1 \\
\hline & Sig. (2-tailed) & .036 & \\
\hline & $\mathrm{N}$ & 10 & 10 \\
\hline
\end{tabular}

*. Correlation is significant at the 0.05 level (2-tailed). 


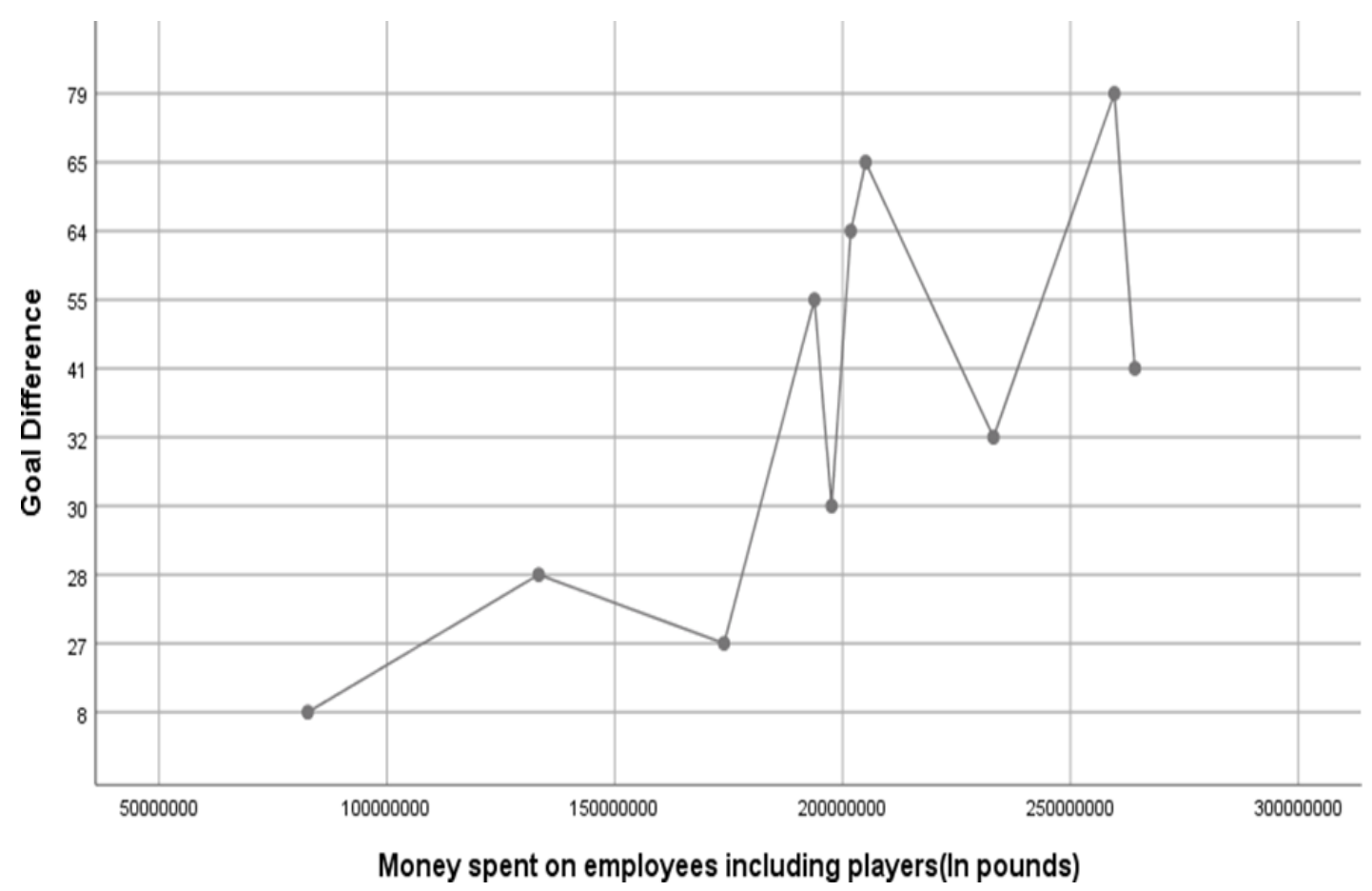

Figure.3 Interpolated line between Goal difference and Average Payroll Costs

Manchester city went through a massive overhaul in terms of money spending as soon as the club was taken over by the City Football Group. One major area where big money was spent was players and personnel. Manchester city soon began signing big names like Yaya Toure, Carlos Tevez, David Silva and Sergio Aguero. Along with players the club also decided to spend on new staff for the players including new physios, Kit managers, dieticians and other medical staff.The graph above shows that there is positive correlation between the money spent on players and personnel and the goal difference in each subsequent season. Goal difference refers to the difference between the goals scored and the goals conceded by each team. This means that the more the club has increased expenditure over the last few years they've looked increasingly better on the table. The anomalies on the graph indicate that even though big money was spent on players, they didn't necessarily always perform due to loss in form, injuries, etc.

Figure 4\&5. Correlation and interpolated line between Average Payroll Costs and Points on Table

Correlations

\section{Aggregate \\ Payroll Costs Points on}

\begin{tabular}{|c|c|c|c|}
\hline \multirow{4}{*}{$\begin{array}{l} \\
\text { Aggreg } \\
\text { ate } \\
\text { Payroll } \\
\text { Costs }\end{array}$} & & & $\mathrm{Tab}$ \\
\hline & $\begin{array}{l}\text { Pearson } \\
\text { Correlation }\end{array}$ & 1 & $.797^{* * *}$ \\
\hline & Sig. (2-tailed) & & .006 \\
\hline & $\mathrm{N}$ & 10 & 10 \\
\hline \multirow{3}{*}{$\begin{array}{l}\text { Points } \\
\text { on } \\
\text { Table }\end{array}$} & $\begin{array}{c}\text { Pearson } \\
\text { Correlation }\end{array}$ & $.797^{* *}$ & 1 \\
\hline & Sig. (2-tailed) & .006 & \\
\hline & $\mathrm{N}$ & 10 & 10 \\
\hline
\end{tabular}




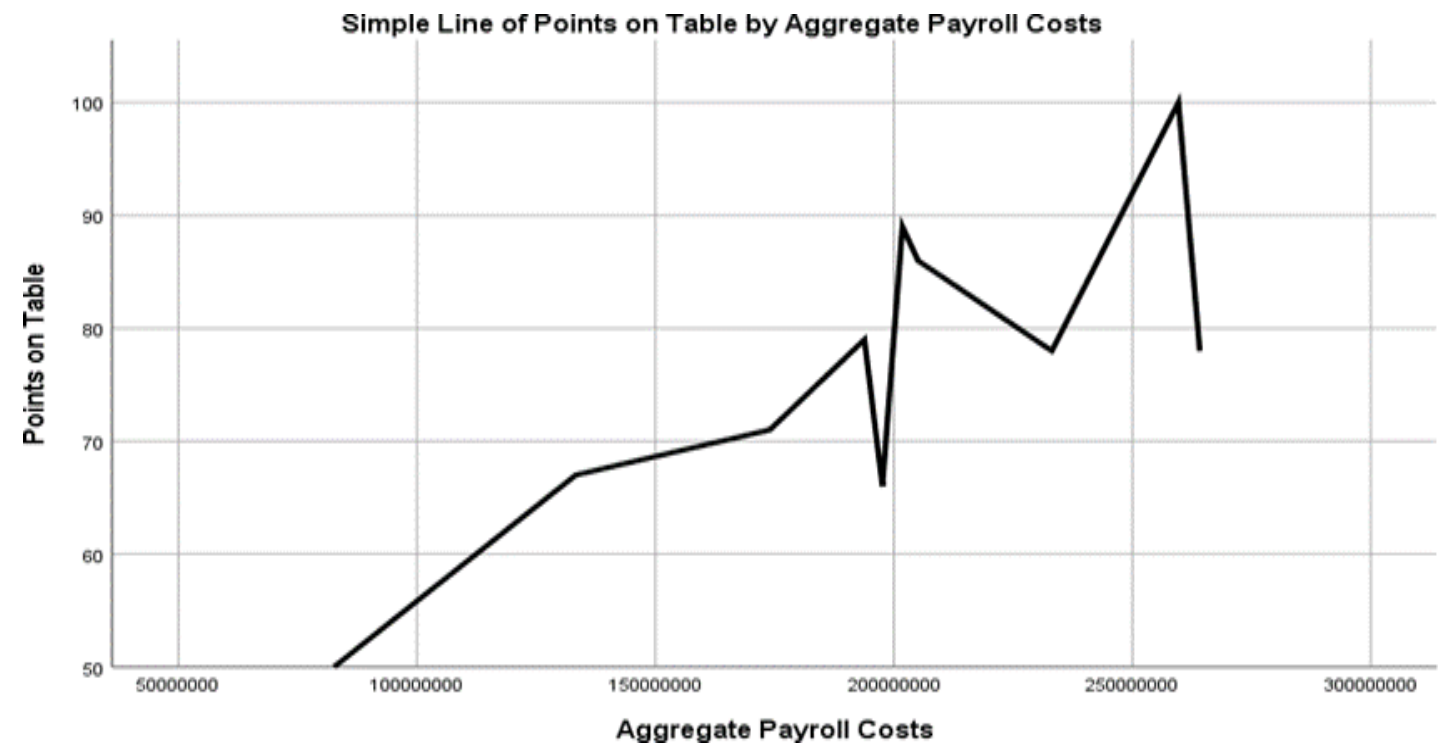

**. Correlation is significantat the 0.01 level(2- tailed).

Big money signings don't always come cheap and players often take big salary packages. Payroll costs went up as city began signing star players, moreover players are often given incentives like goal bonuses, clean sheet bonus for goalkeepers, etc. which are an addition to the basic salary packages.

This particular graph also indicates a positive correlation between increasing payroll costs and points on the table, which means that whenever higher perks and packages have been offered to players they have played well on the pitch leading to an increase in the total points obtained by the team in every successive season.

Figure $6 \& 7$ Correlation and Scatter Point plot with Fit Line between Market value and Points on the Table

\begin{tabular}{l|l}
$\begin{array}{c}\text { Market Value } \\
\text { of the club(In } \\
\text { Pounds) }\end{array}$ & Points on Table
\end{tabular}

\begin{tabular}{|c|c|c|c|}
\hline \multirow[t]{3}{*}{$\begin{array}{l}\text { Market Value } \\
\text { of the club(In } \\
\text { Pounds) }\end{array}$} & $\begin{array}{l}\text { Pearson } \\
\text { Correlation }\end{array}$ & 1 & $.735^{*}$ \\
\hline & Sig. (2-tailed) & & .015 \\
\hline & $\mathrm{N}$ & 10 & 10 \\
\hline \multirow{4}{*}{$\begin{array}{l}\text { Points on } \\
\text { Table }\end{array}$} & Pearson & $.735^{*}$ & 1 \\
\hline & Correlation & & \\
\hline & Sig. (2-tailed) & .015 & \\
\hline & $\mathrm{N}$ & 10 & 10 \\
\hline
\end{tabular}

*. Correlation is significant at the 0.05 level (2-tailed). 


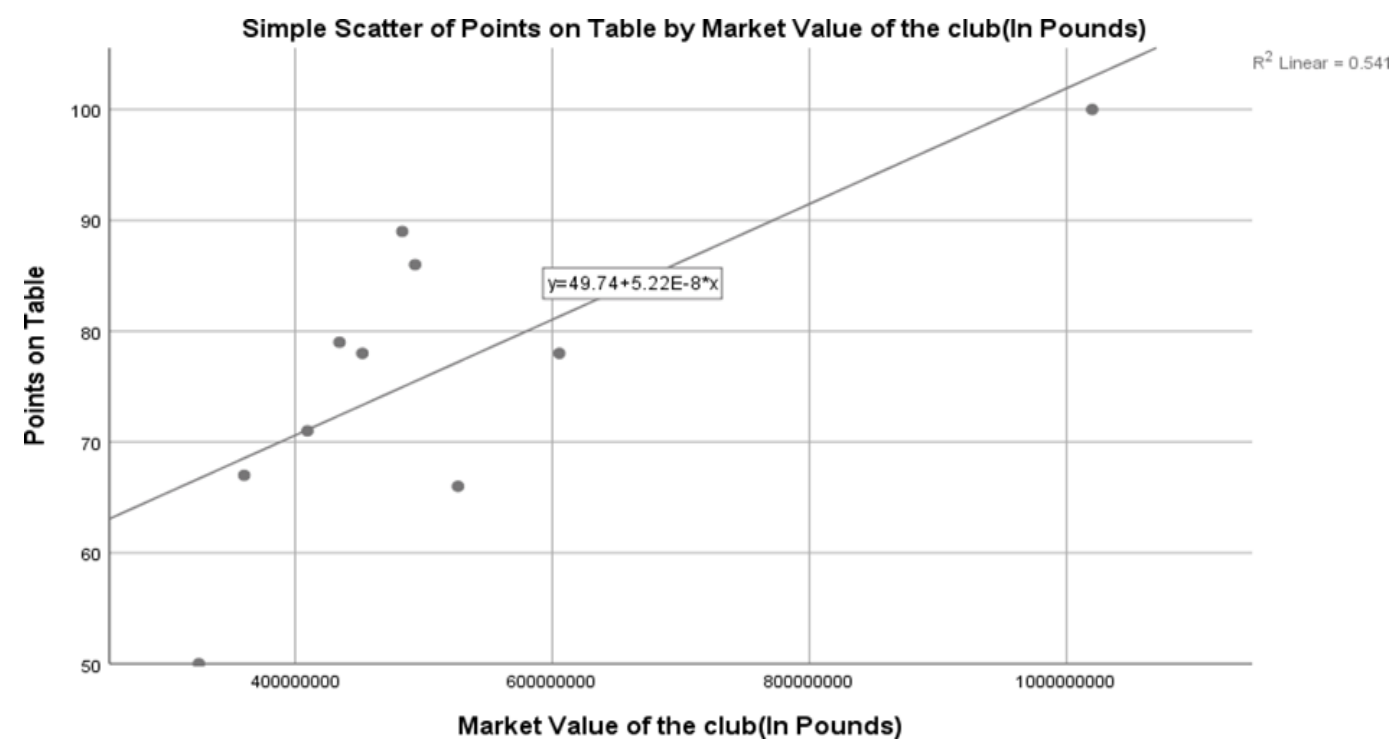

Market value of a football club depends upon a wide range of factors. Among them include trophies won, star players in the playing eleven, Fan base and ticket sales and TV rights

As the graph indicates Manchester City's club value has been growing at an increasing rate since the takeover by Sheikh Mansoor with the club's market value reaching a height of 1.27 bn pounds as of 2018. As the club's value is growing, the club performance subsequently increases every year. Increasing amount of points on the table are an indicator of positive team performance every year.The above graph shows the amount of points every Premier League winner finished the season with. Manchester city set a Premier League record in the 2017-2018 season when manager Pep Guardiola's squad finished the league with a record 100 points and became the first team in doing so.

\section{The rise and fall of Arsenal football Club}

Arsenal football club has always been associated with youth and class. They are also called the invincibles because they won the 2003-04 season undefeated. No other premier league team has achieved this impossible feat. But today they are a mere shadow of what they once used to be. Let us try and find out what exactly happened since then.

In 1996 Arsene Wenger was appointed Arsenal Manager. He instantly gave Arsenal consistency and landed them at a respectable third spot. He signed players like Dennis Bergkamp. In the subsequent year, 1997-98 season, Arsenal won the championship which sent shockwaves in clubs like Manchester United who had been at the helm of the league consistently. Wenger made some great signings like Patrick Vieira, Emmanuel Petit, Freddie Ljungberg and Thierry Henry. In 2001-02 season Arsenal again won the championship. From 1998 till 2001 Arsenal produced great performances very consistently. They held the second place from 1999 till 2001 until they won the championship again. Arsene Wenger was given credit for bringing in new and rigorous training methods along with a refreshing take on nutrition. In 2001-02 season Arsenal again finished second behind Manchester United. In 2003- 04, Arsenal achieved the impossible. They won the league undefeated with 26 wins, 12 draws and 0 losses. Arsenal went on to be undefeated in 47 games and this record still remains. Arsene Wenger during this period signed Sol Campbell, Cesc Fabregas, Jens Lehmann and Robert Pires who proved to be monumental in this Invincible season. In 2004-05 season Arsenal again finished 2nd.

\section{Arsenal's move from Highbury to Emirates}

In 1997, the club decided to move from their traditional home Highbury to a new stadium with a greater capacity. This was seen as a way to earn more television revenue and ticket sales. It took 7 years to finally break ground. Emirates was to be the sponsor of the stadium. The project was completed at the cost 390 million pounds in 2006. Arsenal received no public subsidy for this project. Arsenal started selling their prime talent to finance the project. There was a sudden cash crunch at the club. They reduced player wages. The loan repayment was to be done at a fixed market rate on 260 million pounds to Royal Bank of Scotland over 14 years. From 2006 to 2012 Arsenal sold Patrick Vieira, Dennis Bergkamp, Ashley Cole, Theirry Henry, Jens Lehmann, Cesc Fabregas and Robin Van Persie to name a few. The performances were below the standards that fans expected them to be. They were consistently in the top 4 of the premier league but they did not really compete for the title. There was a direct correlation between the cash crunch at the club due to loan repayments and the selling of players, low transfer budgets and ultimately sub-par performances. Arsenal consistently qualified for the Champions league football which was a great feat considering the brutal competition in the premiership. In 2003, Roman Abravomich, a 
Russian billionaire, became the owner of Chelsea Football Club and City football group owned by Sheikh Mansour, member of Royal family of Abu Dhabi bought out Manchester city in 2008. It was the same time when Arsenal was caught up in loan repayments and low transfer budgets. Arsenal sold many of their players to direct competitors like Chelsea, Manchester United and Manchester City.

Arsenal are still recovering from post Invincible era.

Table 1. Positions of 3 clubs from 1996-2019:

\begin{tabular}{|c|c|c|c|}
\hline Year & Arsenal (Position) & Chelsea (Position) & Man City (Position) \\
\hline $1996-97$ & 3 & 6 & 14 \\
\hline $1997-98$ & 1 & 4 & - \\
\hline 1998-99 & 2 & 3 & - \\
\hline 1999-2000 & 2 & 5 & - \\
\hline $2000-01$ & 2 & 6 & 18 \\
\hline 2001-02 & 1 & 6 & - \\
\hline $2002-03$ & 2 & 4 & 9 \\
\hline 2003-04 & 1 & 2 & 16 \\
\hline $2004-05$ & 2 & 1 & 8 \\
\hline $2005-06$ & 4 & 1 & 15 \\
\hline $2006-07$ & 4 & 2 & 14 \\
\hline $2007-08$ & 3 & 2 & 9 \\
\hline $2008-09$ & 4 & 3 & 10 \\
\hline $2009-10$ & 3 & 1 & 5 \\
\hline $2010-11$ & 4 & 2 & 3 \\
\hline $2011-12$ & 3 & 6 & 1 \\
\hline $2012-13$ & 4 & 3 & 2 \\
\hline $2013-14$ & 4 & 3 & 1 \\
\hline $2014-15$ & 3 & 1 & 2 \\
\hline $2015-16$ & 2 & 10 & 4 \\
\hline $2016-17$ & 5 & 1 & 3 \\
\hline $2017-18$ & 6 & 5 & 1 \\
\hline $2018-19$ & 5 & 3 & 1 \\
\hline
\end{tabular}

As highlighted above, we can see a brilliant run by Arsenal till 2005-06 season. They even reached the champion's league final that year. As soon as they had a cash crunch due to shift to Emirates Stadium, it started to reflect on the points table. On the contrast, Chelsea and Manchester City who were acquired by affluent owners in 2003 and 2008 respectively show a sharp rise on the points table.

This clearly shows the effect that influx and outflux of money had on the performances of the teams. 
Figure 8. Graphical representation of Ranks of Teams from 1996-2019

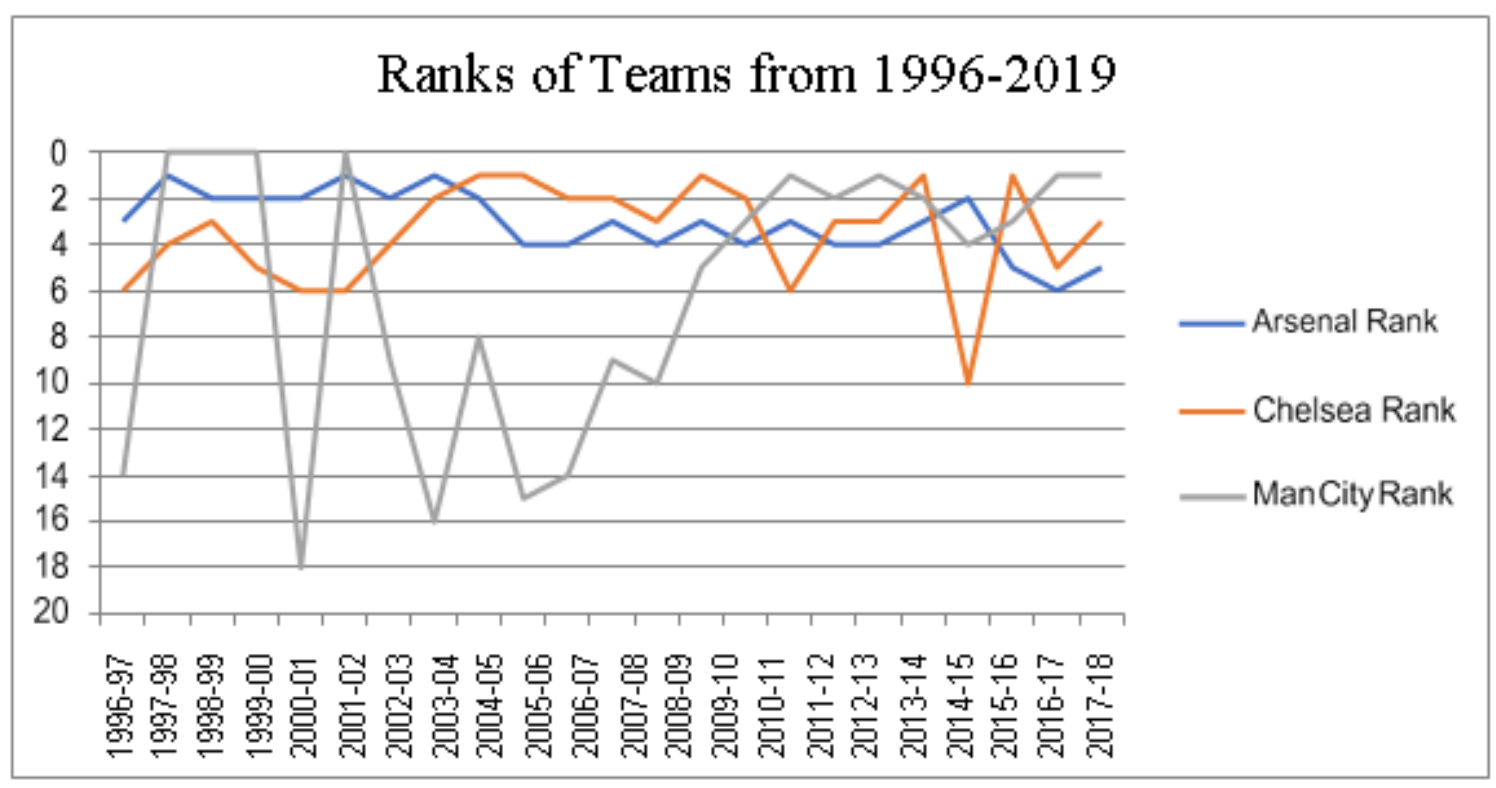

\section{Conclusion}

In the past 3 years, the transfer budgets of all big European clubs have significantly gone up and every year a new transfer record is made. All this is done in pursuit of the ultimate glory. Football is a sport that resonates with billions of people and the sport has worshippers all across the globe. Winning a trophy means more than one can imagine and that is the prime motivation for the clubs to spend to the degree to which they do. In case of Arsenal, as soon as they ran out of cash, their performances went down and even their most charismatic players could not do much as the overall investment in the club went down.In case of Manchester City and Chelsea, as soon as they were acquired by people with deep pockets, their luck changed overnight. It did not even take both the teams two years to win a premier league title after they were acquired. They had not won in decades. That is a data point that simply put things into perspective. Our data and recent trends in football tell us that the monetary investment in the club has a direct correlation with the performance of players on the field. Today, football has become moneyball. With more money, a club can acquire star players, successful coaching staff and a top of the line medical team. All these factors together play a major role in overall success of the club. Having said all that, this sport has numerous intangibles. One cannot predict the result of every game. Miracles happen on a regular basis. Sometimes the spirit beats statistics and that is the beauty of this sport. We have tried to show the general trend in today's game but there will always be outliers like Leicester City and A S Monaco.

\section{References}

- $\quad$ http://content.mcfc.co.uk/ /media/Files/Annual\%20Report/Annual\%20report\%201112\% 20FINAL.pdf

- $\quad$ https://www.premierleague.com/stats/records

- $\quad$ https://www.mancity.com/news/club-news/club.../mcfc-release-2014-15-annual-report

- $\quad$ https://www.arsenal.com/the-club/corporate-info/arsenal-holdings-financial-results

- https://annualreport2018.mancity.com/

- https://annualreport2017.mancity.com/

- https://www.premierleague.com/transfers

- (Fullard, 2012)

- $\quad$ (Miao He, 2015)

- $\quad$ (Manchester City Exposed, 2018)

- (Mohammad, 2011) 